\title{
Proses Adopsi Inovasi Pupuk Organik Cair Mikro Organisme Lokal (Mol) di Kelurahan Gebang Kecamatan Patrang Kabupaten Jember
}

\author{
Frida Dewi Alfina Rahmah ${ }^{1)}$ \\ Muhammad Zaenal Arifin ${ }^{2)}$ \\ Khairil Anam 3) \\ 1)2)3)Program Studi Agribisnis Universitas Jember, Indonesia \\ e-mail: fridadewi66@gmail.com \\ Diterima : November 2018; Disetujui: Januari 2019; Dipublish: April 2019
}

\begin{abstract}
Abstrak
Pupuk organik cair mikro organisme lokal (MOL) adalah pupuk yang terbuat dari bahan dasar kotoran hewan yaitu urine hewan tersebut, perasan sari buah busuk, air kelapa muda, dan gula aren. Adops iovasi Pupuk organik cair mikro organisme lokal (MOL) ini merupakan suatu upaya untuk mewujudkan pembangunan pertanian dengan melakukan peningkatan produksi pada usahatani di Kelurahan Gebang Kecamatan Patrang Kabupaten Jember. Penelitian ini bertujuan untuk mendeskripsikan tahapan adopsi Pupuk organik cair mikro organisme lokal (MOL) yaitu meliputi tahap pengetahuan, sikap, keputusan, implemetasi, dan konfirmasi. Penentuan lokasi menggunakan purposive method. Lokasi penelitian ini berada di Kelurahan Gebang Kecamatan Patrang Kabupaten Jember. Metode penelitian menggunakan deskriptif kualitatif dengan pendekatan studi kasus. Pengumpulan data dengan metode observasi, wawancara, dan pengumpulan dokumen. Metode analisis data menggunakan model analisis Miles dan Huberman yaitu dengan empat tahap meliputi pengumpulan data, kondensasi data, penyajian data serta penarikan kesimpulan. Hasil penelitian menunjukkan bahwa pengetahuan petani dipengaruhi oleh variable individu, interaksi, dan keaadaan soaial ekonomi, petani menerapkan inovasi pupuk organik cair mikro organisme lokal (MOL), petani menerima dan menerapkan adanya inovasi tersebut secara terus menerus.
\end{abstract}

Kata Kunci: implementasi, keputusan, konfirmasi, pengetahuan, sikap

\begin{abstract}
The micro-organism local liquid organic fertilizer (MOL) is a fertilizer made from basic ingredients of animal manure (animal urine), the squeezing rotten fruit juice, young coconut water, and palm sugar. This adoption of the innovation of the micro-organism local liquid organic fertilizer (MOL) is an effort to actualize the agricultural development by increasing production on farming in Gebang, Patrang, Jember. This study aimed to describe the stages of the adoption of the micro-organism local liquid organic fertilizer (MOL), which included the stages of knowledge, attitudes, decisions, implementation, and confirmation. The purposive method was used to determine the research area. This study was conducted in Gebang, Patrang, Jember. The research method used was descriptive qualitative with a case study approach. Observation, interview, and document collection were used as the data collection method. The data was analyzed by using the method of Miles and Huberman's model of qualitative data analysis, namely with four stages including data collection, data condensation, data display, and conclusion drawing. The results of the study showed that farmers knowledge was influenced by individual variables, interactions, and socio economic circumstance, the farmers apply the innovation of micro-organism local liquid organic fertilizer (MOL), the farmers accepted and applied the innovation continuously.
\end{abstract}

Keywords: attitudes; confirmation; decisions; implementation; knowledge 


\section{PENDAHULUAN}

Sektor pertanian sampai saat ini masih memegang peranan penting dalam menunjang perekonomian nasional. Peran sektor pertanian dalam perekonomian indonesia cenderung menurun namun masih dianggap penting dan berpotensi untuk dikembangkan. Sebagian besar kebutuhan masyarakat saat ini berasal dari sektor pertanian. Kebutuhan hidup yang semakin besar harus diimbangi dengan pengembangan sektor pertanian di indonesia untuk usaha pemenuhan kebutuhan masyarakat indonesia. Pengembangan sektor pertanian harus diterapkan di tiap - tiap daerah sesuai dengan potensi yang ada.

Pengembangan pada sektor pertanian saat ini dapat dilakukan dengan berbagai cara salah satunya yaitu dengan penggunaan pupuk organik dalam meningkatkan produktivitas hasil usahatani. Pupuk organik telah banyak digunakan oleh petani di Kecamatan Patrang Kabupaten Jember salah satunya adalah jenis pupuk organik cair mikro organisme lokal (MOL).

Bahan bahan yang digunakan dalam pupuk organik cair mikro organisme lokal (MOL) oleh petani di Kelurahan Gebang Kecamatan Patrang Kabupaten Jember menggunakan bahan bahan organik yang ada disekitar. Petani memanfaatkan bahan organik yang tidak digunakan seperti kotoran kambing, kotoran sapi, dan buahbuahan busuk, bahan tambahan lainnya adalah air kelapa muda dan gula aren. Pupuk ini dibuat berbahan dasar organisme lokal yang terdapat disekitar petani. Bahan-bahan yang sangat mudah didapat membuat sebagian besar petani dapat dengan mudah membuat pupuk MOL dan mengaplikasikannya ke tanaman yang mereka budidayakan.

Proses adopsi inovasi pupuk orgaik cair MOL oleh petani melalui berbagai macam tahapan sebelum pupuk MOL benarbenar di adopsi oleh petani di Kelurahan
Gebang Kecamatan Patrang Kabupaten Jember terutama pada kelompok tani Kedawung Lor. Inovasi pupuk organik cair MOL sangat mudah untuk dibuat dan diaplikasikan oleh petani namun ada beberapa hambatan yang menyebabkan tidak semua petani mengadopsi inovasi pupuk organik cair MOL tersebut, di harapkan penelitian ini dapat menunjang keberhasilan proses adopsi inovasi pupuk organik cair MOL oleh petani di Kelurahan Gebang Kecamatan Patrang Kabupaten Jember.

Penelitian ini bertujuan untuk mengetahui tahapan proses adopsi inovasi pupuk cair MOL oleh kelompok tani kedawung lor di Kelurahan Gebang Kecamatan Patrang Kabupaten Jember.

Hasil dari penelitian terdahulu oleh Nurahman (2007) dengan judul "Respon Petani Terhadap Sistem Tanam Padi Jajar Legowo Pada Prima Tani di Desa Sidodadi Kecamatan Sukosewo Kabupaten Bojonegoro" didapatkan hasil bahwa bahwa, faktor yang mempengaruhi tingkat adopsi petani dalam penerapan sistem tanam jajar legowo yaitu meliputi faktor ekstern dan intern.. Penelitian lainnya oleh Hajrah Lalla (2009) dengan judul "Adopsi Petani Padi Sawah Terhadap Sistem Tanam Jajar Legowo 2:1 di Kecamatan Polong Bangkeng Utara Kabupaten Takalar" mengatakan bahwa, tingkat adopsi teknologi jajar legowo 2:1 masuk dalam kategori rendah, yakni sebanyak $60,78 \%$ petani responden. Terdapat faktor internal dan faktor eksternal yang mempengarui proses adopsi petani tersebut. Penelitian selanjutnya adalah Hendra Darussalam (2017) dengan judul "Proses Adopsi Inovasi Pupuk Cair Organik (Biofish) Berbahan Dasar Ikan Laut pada Komoditas Padi di Kecamatan Muncar Kabupaten Banyuwangi" dengan hasil penelitian bahwa pengetahuan petani tentang pupuk biofish baik, para petani juga suka dalam menggunakan pupuk organik, 
para petani menerima adanya inovasi pupuk biofish.

\section{METODE PENELITIAN}

Penelitian ini merupakan peneitian deskriptif kualitatif dengan metode penelitian studi kasus yaitu meneliti secara mendalam sesuatu dengan menjelaskan bagaimana rancangan kegiatan yang ada mengenai manusia atau dalam kelompok, organisasi atau individu, peristiwa di wilayah tersebut dan apa saja kasus yang ada.

Lokasi penelitian ditentukaan secara sengaja yaitu dengan purposive method $\mathrm{di}$ Kelurahan Gebang Kecamatan Patrang Kabupaten Jember karena merupakan wilayah yang memiliki potensi pada sektor pertanian serta terdapat inovasi-inovasi baru yang diperkenalkan untuk mengembangkan potensi sektor pertanian di wilayah tersebut.

Metode penentuan informan yang digunakan dalam penelitian ini adalah metode purposive sampling yaitu dengan pertimbangan khusus sehingga layak dijadikan responden. Key informan yang dipilih adalah ketua kelompok tani karena dianggap memiliki kriteria paling lengkap sesuai dengan ketentuan peneliti.

Data yang digunakan dalam penelitian ini adalah data primer dan data sekunder. Data primer dari penelitian ini akan didapat dari wawancara langsung dari informan dan dalam pelaksanaan observasi. Data sekunder dalam penelitian ini dapat berupa data dari catatan lapang, foto atau video yang kita dapatkan pada saat proses penelitian. Pengumpulan data dilakukan dengan cara observasi, wawancara, dan pengumpulan dokumen. Penelitian ini di analisis menggunakan model analisis Miles dan Huberman yaitu terdiri dari empat alur kegiatan meliputi pengumpulan data, kondensasi data, penyajian data serta penarikan kesimpulan.
Keabsahan data diuji menggunakan uji credibility, uji transferability, uji dependability, dan uji confirmability. Untuk menguji kredibilitas dilakukan dengan triangulasi sumber yaitu dengan cara mengecek data yang diperoleh melalui beberapa sumber.

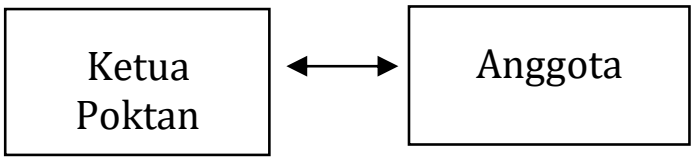

Gambar 1. Bagan Triangulasi Sumber.

Terminologi :

1. Pengetahuan merupakan tingkat ilmu yang dimiliki petani berdasarkan pengalamannya selama kegiatan pengadopsian pupuk organik cair pada usaha taninya.

2. Sikap merupakan pemikiran petani yang nantinya akan diimplemantasikan menjadi perilaku terkait pengadopsian pupuk organik cair pada usaha taninya.

3. Pengambilan keputusan merupakan suatu tindakan akhir yang sengaja dipilih oleh petani berdasarkan pertimbanganpertimbangan tertentu terkait pengapdosian pupuk organik cair pada usaha taninya

4. Implementasi yaitu cara yang dilakukan petani untuk menerapkan pupuk organik cair MOL pada tanaman usaha taninya agar mencapai tujuan yang diinginkan.

5. Konfirmasi adalah keputusan yang diambil petani untuk menggunakan pupuk organik cair MOL untuk seterusnya.

\section{HASIL DAN PEMBAHASAN}

A. Pengetahuan Petani Tentang Inovasi Pupuk Organik Cair Mikro Organisme Lokal (MOL) di Kelurahan Gebang Kecamatan Patrang Kabupaten Jember Menurut Martin dan Oxman dalam Kusrini (1988), pengetahuan merupakan kemampuan untuk membentuk model mental yang menggambarkan obyek dengan tepat dan mempresentasikannya dalam aksi 
yang dilakukan terhadap suatu obyek. Inovasi pupuk organik cair mikro organisme Lokal (MOL) mulai menjadi pilihan petani dan kebutuhan bagi para petani dalam melakukan kegiatan budidaya usahatani di Kelurahan Gebang Kecamatan Patrang Kabupaten Jember. Variabel yang mempengaruhi suatu pengambilan keputusan dalam suatu inovasi antara lain yaitu variabel individu, perilaku komunikasi, dan sosial ekonomi masyarakat.

Variabel individu merupakan suatu bagian dari petani yang memiliki pengaruh yang sangat signifikan terhadap pengambilan keputusan dalam kegiatan pertaniannya, seperti umur petani yang sudah tua akan mempengaruhi kinerja dalam melakukan kegiatan budidaya kemudian seperti pendidikan petani yang rendah akan mempengaruhi tingkat pengetahuan yang dimiliki oleh seorang petani.

Komunikasi tidak akan lepas dari suatu proses adopsi inovasi yang di dalamnya terdapat Interaksi. Interaksi komunikasi merupakan bagian dalam proses adopsi inovasi pupuk organik cair, dimana petani memiliki pengetahuan kemudian menyikapi tentang inovasi pupuk organik cair. Pengaplikasian inovasi pupuk organik cair perlu dilakukan pengawasan dan pengarahan tentang bagaimana cara penggunaan pupuk organik cair, sehingga para petani dalam penerapannya dapat sesuai dengan aturan pemakaian yang disarankan. Kondisi sosial ekonomi petani di Kelurahan Gebang Kecamatan Patrang Kabupaten Jember sebagian besar berprofesi sebagai petani karena masih tersedianya lahan yang cukup banyak dan minimnya lapangan pekerjaan yang lain. Petani di Kelurahan Gebang masih merupakan model petani subsisten yang artinya masih mementingkan bagaimana cara memenuhi kebutuhan hidupnya saja dan masih belum berorientasi pada keuntungan dari hasil usahatani yang petani budidayakan.
Berprofesi sebagai petani disebabkan antara lain yaitu kurangnya keterampilan dan pengetahuan khusus, kurangnya lapangan pekerjaan dan juga menjadi profesi turuntemurun. Pupuk organik cair mikro organisme lokal (MOL) memberikan pengaruh positif terhadap ekonomi petani karena dengan penggunaan pupuk organik cair tersebut dapat mengurangi biaya dan menjaga kelestarian lingkungan.

B. Sikap Petani Terhadap Inovasi Pupuk Organik Cair Mikro Organisme Lokal (MOL) Di Kelurahan Gebang Kecamatan Patrang Kabupaten Jember

Menurut Soekartawi dalam Hendra (1988), sifat-sifat inovasi dan peran penyuluh akan menentukan tingkat kecepatan dari suatu inovasi, beberapa sifatsifat inovasi antara lain yaitu: keuntungan relatif, kesesuaian, kompleksitas, kemudahan untuk dicoba dan kemudahan untuk diamati.

a. Keuntungan Relatif

Sifat keuntungan relatif dapat dilihat berdasarkan kelebihan yang diberikan oleh inovasi pupuk organik cair MOL. Keuntungan relative akan mempengaruhi seorang individu untuk mengadopsi suatu inovasi. Kelebihan pupuk organik cair MOL menurut informan yaitu:

1. Tanaman menjadi lebih tahan penyakit

2. Biaya murah

3. Ramah lingkungan

4. Pembuatan mudah

5. Aman terhadap kesehatan

6. Mengambalikan kesuburan tanah

b. Kesesuaian

Inovasi pupuk oganik cair MOL sesuai dengan kondisi lingkungan sosial masyarakat juga berpengaruh positif dan tidak bertentangan dengan nilai budaya yang ada di Kelurahan Gebang dalam artian yaitu pengaplikasian pupuk organik cair MOL memberikan dampak posistif dan tidak bertolak belakang dengan nilai dan kebiasan 
yang ada di tengah-tengah masyarakat karena pupuk organik cair MOL aman dan memberikan dampak positif terhadap kegiatan usahatani di Kelurahan Gebang Kecamatan Patrang Kabupaten Jember.

\section{c. Kompleksitas}

Kerumitan menjadi sebuah tantangan tersendiri bagi petani dalam pengaplikasian pupuk organik cair MOL. Petani merasakan kemudahan dalam pengaplikasian dengan cara melakukan penyemprotan pupuk organik cair MOL terhadap tanaman budidaya petani.

d. Kemudahan untuk dicoba

Tingkat kemudahan inovasi pupuk organik cair MOL dapat terlihat dari bagaimana cara petani dalam melakukan tanpa ada kesulitan berarti dan mudah dalam pengaplikasiannya. Penggunaan pupuk organik cair MOL oleh petani yaitu dengan mencampur berbagai macam bahan organik seperti urine hewan, sari buah busuk, air kelapa muda, dan gula aren yang kemudian didiamkan kurang lebih satu minggu.

e. Kemudahan untuk diamati

Tanaman terlihat tumbuh lebih kokoh dan kuat karena sistem perakaran yang lebih jauh kedalam tanah dan berbeda ketika menggunakan pupuk kimia perbedaan yang terlihat seperti daun yang lebih hijau dan bobot biji yang semakin berisi tetapi memerlukan waktu yang lebih lama untuk melihat hasil yang diperoleh.

C. Keputusan Petani Mengadopsi Pupuk Organik Cair Mikro Organisme Lokal (MOL) Di Kelurahan Gebang Kecamatan Patrang Kabupaten Jember

Petani di Kelurahan Gebang Kecamatan Patrang Kabupaten Jember sebagian besar menyukai penggunaan pupuk organik cair MOL sebagai pupuk pelengkap dari pupuk kimia yang digunakan. Pupuk organik cair selain dapat menghemat biaya yang dikeluarkan juga mempunyai manfaat bagi kesuburan lahan dan kelestarian lingkungan.
D. Implementasi Petani Dalam Inovasi Pupuk Organik Cair Mikro Organisme Lokal (MOL) di Kelurahan Gebang Kecamatan Patrang Kabupaten Jember

Tahapan selanjutnya setelah tahapan keputusan yaitu tahapan implementasi. Implementasi adalah tahap pengaplikasian inovasi pupuk organik cair MOL di lapang pada tanaman budidaya petani. Proses pengaplikasian pupuk organik cair MOL yang dilakukan oleh petani sesuai dengan arahan yang diberikan oleh penyuluh dan petani juga terkadang juga mencoba untuk menemukan formulasi tersendiri agar pupuk organik cair MOL tersebut memiliki manfaat yang lebih banyak dalam penerapannya.

E. Konfirmasi Petani Dalam Inovasi Pupuk Organik Cair Mikro Organisme Lokal (MOL) di Kelurahan Gebang Kecamatan Patrang Kabupaten Jember

Tahap konfirmasi merupakan tahap kepastian petani dalam penerapan pupuk organik cair MOL kedepannya apakah lanjut menerapkan atau tidak. Alasan utama petani di Kelurahan Gebang Kecamatan Patrang Kabupaten Jember menggunakan pupuk organik cair MOL terus menerus dan berkelanjutan karena sesuai dengan kondisi sosial ekonomi petani karena dengan menggunakan pupuk organik cair MOL hanya memerlukan biaya yang relatif rendah dibandingkan dengan biaya pembelian pupuk kimia sehingga akan mengurangi biaya usahatani yang dikeluarkan dan juga dengan penggunaan pupuk organik cair MOL dapat meningkatkan kesuburan tanah serta bahan baku yang mudah untuk diperoleh.

\section{SIMPULAN}

Pengetahuan petani terhadap adopsi inovasi pupuk organik cair MOL dipengarui oleh variable individu, perilaku komunikasi, dan sosial ekonomi masyarakat. Sikap petani terkait inovasi dipengaruhi oleh keuntungan relatif, kesesuaian, kompleksitas, kemudahan untuk dicoba dan kemudahan 
untuk diamati inovasi pupuk organik cair MOL tersebut. Petani di Kelurahan Gebang Kecamatan Patrang Kabupaten Jember mengaplikasikan inovasi pupuk organik cair MOL sesuai dengan pengetahuan petani. Petani menerima dan mengaplikasikan adanya inovasi pupuk organik cair MOL tersebut secara terus menerus.

\section{UCAPAN TERIMAKASIH}

Ucapan terimakasih yang pertama kepada kedua orang tua kami yang selalu mendukung kami dalam hal positif apapun. Ucapan terimakasih disampaikan kepada ketua kelompok tani yang bersedia menjadi key informan yang sangat ramah. Ucapan terimakasih selanjutnya kepada dosen pengampu kami Prof. Dr. Ir. Rudi Wibowo, MS dan ibu Illia Seldon Maghfiroh, SE, MP. Yang telah membimbing dan memberi ilmu kepada kami untuk merealisasikan artikel ini. Ucapan selanjutnya kepada seluruh pihak yang terlibat dan telah memberi dukungan semangat kepada kami.

\section{DAFTAR PUSTAKA}

Darusalam, H., S. Subekti., dan L. Widjayanti. 2017. Proses Adopsi Inovasi Pupur Cair Organik (Biofish) Berbahan Dasar Ikan Laut Pada Komoditas Padi Di Kecamatan Muncar Kabupaten Banyuwangi. Kanal. Vol 6 (1): 9-20.

H Lalla. 2012. Adopsi Petani Padi Sawah Terhadap Sistem Tanam Jajar Legowo 1:2 di Kecamatan Polongbangkeng Utara Kabupaten Takalar. Sains \& Teknologi, 12(3): 255-264.

Kusrini. 2006. Sistem Pakar Teori dan Aplikasi. Yogyakarta: CV Andi Offset.

Nurahman. 2007. Respon Petani Terhadap Sistem Tanam Padi Jajar Legowo Pada Prima Tani Studi Kasus Pada Kelompok Tani Mitra Tani di Desa Sidodadi Kecamatan Sukosewo Kabupaten Bojonegoro. Skripsi. Universitas Brawijaya. Malang.

Soekartawi. 1988. Prinsip dasar komunikasi pertanian. Jakarta: Universitas Indonesia (UI-Press). 